\title{
Detection of Newcastle Disease Virus Minor Genetic Variants by Modified Single-Stranded Conformational Polymorphism Analysis
}

\author{
Lukasz Rabalski, ${ }^{1}$ Krzysztof Smietanka, ${ }^{2}$ Zenon Minta, ${ }^{2}$ and Boguslaw Szewczyk ${ }^{1}$ \\ ${ }^{1}$ Department of Recombinant Vaccines, Intercollegiate Faculty of Biotechnology, University of Gdansk, \\ Medical University of Gdansk, Kladki 24, 80-822 Gdansk, Poland \\ ${ }^{2}$ The National Veterinary Research Institute, Aleja Partyzantow 57, 24-100 Pulawy, Poland \\ Correspondence should be addressed to Lukasz Rabalski; lukasz.rabalski@biotech.ug.edu.pl
}

Received 24 November 2013; Accepted 12 March 2014; Published 10 April 2014

Academic Editor: Oscar Perng

Copyright (C) 2014 Lukasz Rabalski et al. This is an open access article distributed under the Creative Commons Attribution License, which permits unrestricted use, distribution, and reproduction in any medium, provided the original work is properly cited.

\begin{abstract}
Newcastle disease and Avian Influenza are considered to be the most dangerous fowl diseases which may cause huge economic losses. Newcastle disease is caused by the enveloped, and single-stranded RNA virus (NDV, APMV-1; belonging to Paramyxoviridae family), which can be further divided into sixteen different genotypes grouped into five pathotypes according to their pathogenicity. It has been reported that low pathogenic virus can greatly increase its pathogenicity even during a single passage. Additionally, due to the widespread use of live vaccines, a mixture of two or more different viruses in one sample can be detected. Hence, there is a great need for establishment of fast, inexpensive, sensitive, and relatively simple diagnostic method for multistrain and quasispecies detection of NDV infection. In this paper we describe a diagnostic method based on RT-PCR followed by a modified version of single-stranded conformational polymorphism analysis using short DNA fragments of gene encoding viral $\mathrm{F}$ protein. The method allows for rapid diagnosis of genetic variant emerging from previously stable population which may prevent the spread of the pathogenic viral variant.
\end{abstract}

\section{Introduction}

Newcastle disease is an avian viral disease that endemically occurs in Asia, Africa, and Central and South America [1]. The etiological cause of the disease is an enveloped, nonsegmented, negative-sense, and single-stranded RNA virus belonging to Avulavirus genus of Paramyxoviridae family. This genus consists of twelve serotypes of Avian Paramyxoviruses [2]. Newcastle disease virus (NDV) is designated as APMV-1 [3]. It can be further divided into sixteen different genotypes $[4,5]$.

NDV genome contains 15186, 15192, or 15198 nucleotides depending on genotype and encodes six proteins in the following order: NP (nucleocapsid protein), P (phosphate polymerase cofactor protein), M (membrane associated matrix protein), F (fusion surface glycoprotein), HN (hemagglutinin-neuraminidase surface glycoprotein), and L (large RNA dependent RNA-polymerase) [6-8]. Paramyxovirus particles usually enter the host organism via the respiratory or gastrointestinal epithelial cells. F protein is activated by $\mathrm{HN}$ protein which promotes junctions and fusion of viral and host membranes [9]. Matrix protein dissolves and releases helical nucleocapsid into the cytoplasm of the infected cell [10]. After transcription and translation, newly formed progeny virions bud out of the cell [11].

Newcastle disease is widely spread throughout the globe and is considered to be one of the two most dangerous poultry diseases (second is the avian influenza) that cause huge economic losses in poultry production. The loss of US $\$ 161$ million by the US Government in 2002 after the outbreak of Newcastle disease in California is one of the most recent cases of the disease.

The name of the disease is derived from the British city "Newcastle-upon-Tyne," near which it was diagnosed in 1926 for the first time. Almost simultaneously, in the same year, the disease was discovered on Java Island in Indonesia [12]. It 
was experimentally proven that NDV infects at least 236 avian species [13]. Human infections are rare and usually exhibit as eye conjunctivitis; several infections in pigs have been reported $[14,15]$. Naturally selected or laboratory adapted strains of the NDV are thoroughly studied, some of them found application as new oncolytic virotherapeutics that can be used to treat human cancers like melanoma $[15,16]$.

The main reservoirs of the APMV-1 are waterfowl and migratory birds $[17,18]$. During infection with low pathogenic strains often they do not exhibit clinical signs, which allows for the "unnoticed" spread of the virus. The highest mortality (even higher than $90 \%$ in $2-6$ dpi) among infected birds is observed in domestic fowl (Gallus gallus domesticus) [1]. Virulence of a strain depends mainly on the short amino acid sequence of the precursor protein responsible for fusion of membranes [19]. Highly pathogenic NDV usually contains the following sequence: $C_{-}{ }^{112} \mathrm{R} / \mathrm{K}-\mathrm{R}-$ $\mathrm{Q} / \mathrm{K} / \mathrm{R}-\mathrm{R} / \mathrm{K}-\mathrm{R}-\mathrm{F}^{117}-\mathrm{N}$, while low pathogenic has $\mathrm{C}-{ }^{112} \mathrm{G} / \mathrm{E}-$ K/R-Q-G/E-R-L ${ }^{117}-\mathrm{N}$. These motifs are recognized by different cellular proteases which limit the ability for virus propagation only to specific host tissue [20, 21]. World Organisation for Animal Health distinguishes five pathotypes of Newcastle disease virus: viscerotropic and neurotropic velogenic (highest mortality rate, Intracerebral Pathogenicity Index $>1,5$ ), mesogenic (low mortality but moderate signs from respiratory system, ICPI 1,5-0,7), lentogenic (mild respiratory infection with no mortality, life-vaccine strains, ICPI $<0,7$ ), and asymptomatic (no signs or subclinical enteric infections) [22].

Although vaccines based on low pathogenic variants of NDV protect against clinical signs and mortality, they do not prevent infection with highly pathogenic strains, which may be the cause for uncontrolled spread of the virus [23]. This phenomenon may be intensified if chickens are vaccinated at the same time against other viruses (e.g., against infectious bursal disease virus) or if the dose of the vaccine is too small and/or poorly administered [24-26].

Molecular diagnostic methods that employ different variations of RT-PCR and real-time PCR techniques allow for sensitive detection and pathotyping of APMV-1 [27-37]. All techniques based on endonuclease cleavage or probe/primer hybridization to a specific site are very sensitive to mismatches that often produce false-negative results [37, 38]. Methods that use high resolution or standard melting curve analysis are unable to detect multistrain or quasispecies infection without very expensive, time and resource consuming preanalysis [39]. These deficiencies are the most important after the discovery that highly virulent viruses may arise from progenitor viruses of low virulence, as it was shown during Australian 1998-2002 outbreak [40, 41]. Even a single passage in chicken's brain can change virus pathotype to velogenic $[42,43]$.

One of the methods which may help in differentiation as well as in quasi- and multistrain NDV detection is one-step RT-PCR followed by single-stranded conformational polymorphism. Single-stranded conformational polymorphism (SSCP) analysis was first described by Orita et al. [44] who demonstrated that single-stranded DNA fragments with a single base difference can be potentially distinguished on the basis of difference in electrophoretic mobility under native conditions. During the gel run, single-stranded fragments adopt secondary structure depending on the sequence and conditions. Exemplary ssDNA secondary structures are presented in Figure 1. Usually more than one electrophoretic band of ssDNA is observed for a particular DNA fragment due to the fact that often more than one conformer is thermodynamically favorable in experimental conditions. Physicochemical conditions, the most important being ionic strength, $\mathrm{pH}$, and temperature, play an important role in the formation of particular conformers [45-47]. In the modification of this technique named multitemperature singlestranded conformational polymorphism (MSSCP), the electrophoretic gel is run at stringently controlled temperatures which are changed stepwise during the run [48]. SSCP analysis has been recently applied to the identification of genetic variation in several groups of viruses [49-51]. One of the most useful applications of this technique has been in the identification of quasispecies within the population of viruses making it an effective tool in molecular epidemiology studies $[52,53]$.

The purpose of this study was to develop a method for inexpensive, quick, and sensitive identification of NDV variants with a point mutation in gene $\mathrm{F}$ cleavage site that can lead to increase of the pathogenicity. Ideally, the method should allow for detection of minor quasispecies at relatively low cost in routine diagnostic laboratories.

\section{Materials and Methods}

2.1. APMV-1 Strains. Full size or fragments of genomes from three reference strains (vaccine La Sota, vaccine Roakin, and Italy) and three Australian strains (isolated during 1998-2002 outbreak in New South Wales) were tested in this study and are listed in Table 1.

2.2. Template Preparation, RT-PCR Conditions. $\mathrm{nR}$-allantoic fluid from SPF embryonated flock eggs (Lohman, Germany), previously inoculated with La Sota or Roakin NDV strains, was harvested and subjected to RNA extraction using RNeasy Mini Kit according to the manufacturer protocol (Qiagen, USA). RNA from oral and cloacal swabs from chickens infected with La Sota or Roakin NDV strains was purified with the same procedure.

$\mathrm{nD}$-one set of universal (for all Class II APMV-1) degenerate PCR primers for amplification of $123 \mathrm{nt}$ fusion glycoprotein gene fragment was designed. The DNA sequences for this set of primers were as follows: NDV-F (position 4790-4809 in La Sota genome): 5'-GCATACAACAGRACAYTGAC-3' and NDV-R (position 4893-4912 in La Sota genome): $5^{\prime}$-GCCDATAATGGCRCCTATAA-3'. Synthesis of the first strand and amplification of the DNA were carried out during one-step RT-PCR (AccessQuick RT-PCR System, Promega, USA) procedure. The reaction mixture contained $1 \mu \mathrm{L}$ template RNA, $12.5 \mu \mathrm{L}$ AccessQuick Master Mix, $0.5 \mu \mathrm{L}$ $10 \mu \mathrm{M}$ NDV-F primer, $0.5 \mu \mathrm{L} 10 \mu \mathrm{M}$ NDV-R primer, $0.5 \mu \mathrm{L}$ 


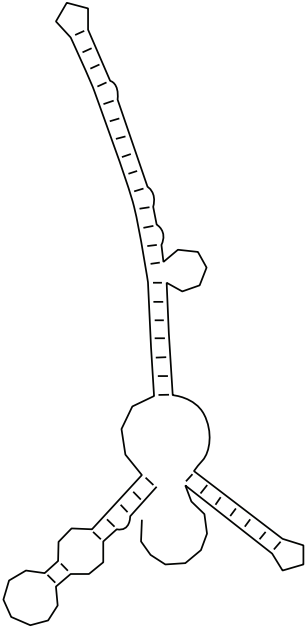

(a)

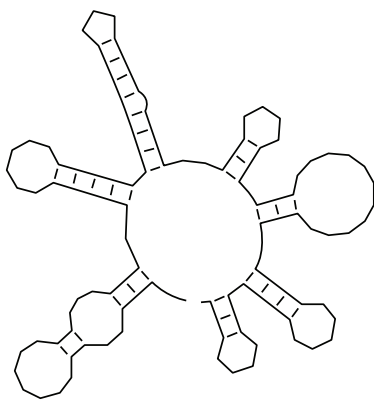

(b)

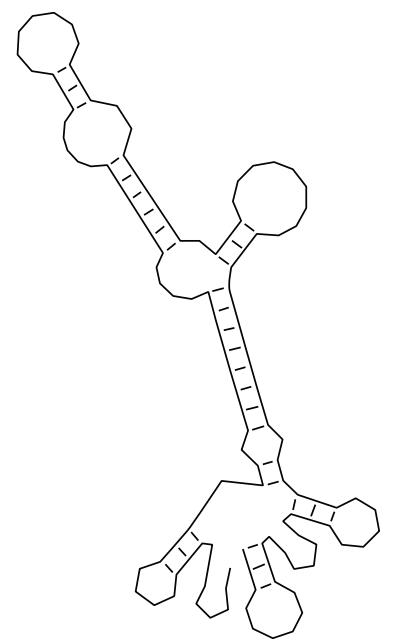

(c)

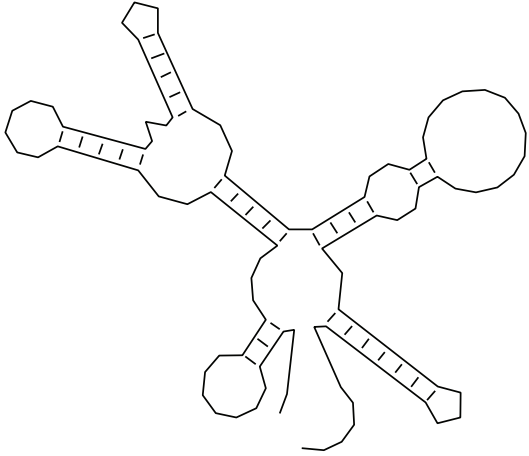

(d)

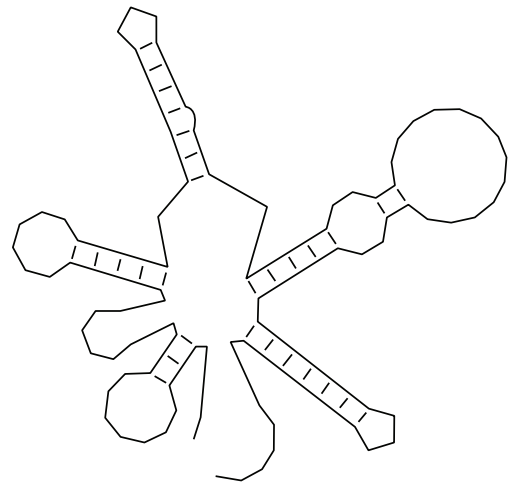

(e)

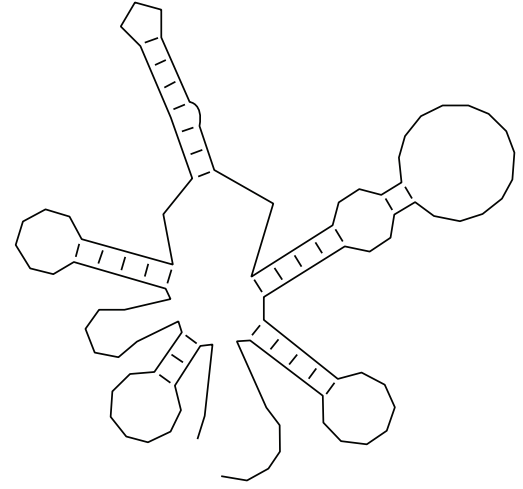

(f)

FIGURE 1: Possible ssDNA conformers of $123 \mathrm{nt}$ fusion protein fragments of La Sota (a), Roakin (b), Italy (c), lentogenic 98-1154 (d), mesogenic 99-0868-2 (e), and velogenic 99-0655 (f) NDV strains. Structures were drawn in Geneious R6 PRO software using ssDNA energy model at $20^{\circ} \mathrm{C}$.

TABLE 1: List of NDV strains with different types of templates for PCR or RT-PCR and highlighted point mutations affecting their virulence.

\begin{tabular}{|c|c|c|c|c|c|}
\hline Strain & Templates* & GenBank acc. number & Nucleotide motif $^{* *}$ & ICPI & Pathotype \\
\hline La Sota & $\mathrm{nR}, \mathrm{aR}, \mathrm{nD}$ & AF077761 & GGGAGACAGGGGCGCCTT & $0.4[1]$ & Lentogenic \\
\hline Roakin & $\mathrm{nR}, \mathrm{aR}, \mathrm{nD}$ & AY289000 & AGGAGACAGAAACGCTTT & $1.45[1]$ & Mesogenic \\
\hline Italy & $\mathrm{nR}, \mathrm{aR}, \mathrm{nD}$ & AY562989 & AGGAGGAAGAAACGCTTT & $1.55[73]$ & Velogenic \\
\hline $98-1154$ & $\mathrm{aR}, \mathrm{aD}$ & AY935491 & AGGAGACAGGGGCGTㅡTT & $0.47[60]$ & Lentogenic \\
\hline $99-0868-2$ & $\mathrm{aR}, \mathrm{aD}$ & AY935496 & AGGAGACAGㅁGGCGTㅡTT & $1.38[60]$ & Mesogenic \\
\hline $99-0655$ & $\mathrm{aR}, \mathrm{aD}$ & AY935494 & 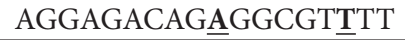 & $1.61[60]$ & Velogenic \\
\hline
\end{tabular}

${ }^{*}$ nR: genomic RNA isolated from live-virus vaccines, aR: RNA obtained by transcription of cloned fusion protein gene fragment from a plasmid, $\mathrm{nD}$ : plasmids with cloned cDNA from RT-PCR of genomic RNA, and aD: plasmids with cloned synthetized fusion protein gene fragment.

${ }^{* *}$ nucleotide sequence for $\mathrm{F}_{0}$ cleavage site (position 4877-4894 in La Sota genome).

(2.5 u) AMV Reverse Transcriptase, and $10.5 \mu \mathrm{L}$ NucleaseFree Water. The reaction conditions were as follows: $1 \mathrm{x}$ [ $45^{\circ} \mathrm{C} 40 \mathrm{~min} ., 95^{\circ} \mathrm{C} 2 \mathrm{~min}$.], $30 \mathrm{x}$ [ $95^{\circ} \mathrm{C} 30 \mathrm{sec} ., 43^{\circ} \mathrm{C} 30 \mathrm{sec}$, $\left.70^{\circ} \mathrm{C} 15 \mathrm{sec}.\right]$, and $1 \mathrm{x}\left[70^{\circ} \mathrm{C} 2 \mathrm{~min}\right]$. PCR products were electrophoresed in $2 \%$ agarose gels using $1 \mathrm{x}$ TAE buffer ( $40 \mathrm{mM}$ TRIS, $20 \mathrm{mM}$ sodium acetate, and $1 \mathrm{mM}$ EDTA adjusted to pH 7.2 with glacial acetic acid) with ethidium bromide and purified (Gel-Out Kit, A\&A Biotechnology, Poland) and cloned into the pJet 1.2 vector (CloneJET PCR
Cloning Kit, Thermo Scientific, USA) in accordance with the manufacturers protocols. The recombinant plasmids were used to transform the TOP10 strain of E. coli competent cells (Life Technologies, USA). Colonies were isolated and they were grown in liquid medium for purification of recombinant plasmids on silica gel columns (Plasmid Mini, A\&A Biotechnology, Poland). After restriction analysis, the recombinant plasmids containing the correct inserts were sent for sequencing to Genomed, Poland. Sequences were 
aligned using the Geneious R6 PRO software created by Biomatters, available from http://www.geneious.com/.

$\mathrm{aD}$-three $145 \mathrm{bp}$ DNA oligonucleotides with sequences exactly the same as those in Australian strains of NDV (position 4790-4934 in La Sota genome) presented in Table 1 were synthetized in Genomed, Poland. These fragments were subjected to cloning, restriction analyses, and sequencing as described above.

aR-all purified and checked for correct sequence plasmids were used as template for transcription reaction by TranscriptAid T7 High Yield Transcription Kit (Thermo Scientific, USA) as instructed by the manufacturer. RNA was checked for lack of DNA contamination by RT-PCR as described above without addition of AMV Reverse Transcriptase.

2.3. MSSCP Analyses. Templates $\mathrm{nR}$ and aR were subjected to RT-PCR and plasmids ( $\mathrm{nD}$ and $\mathrm{aD}$ ) to PCR (no initial $45^{\circ} \mathrm{C}$ 40 min. step or AMV Reverse Transcriptase). For MSSCP analysis, $3 \mu \mathrm{L}$ of DNA was added to $10 \mu \mathrm{L}$ of denaturing buffer $(0.1 \mathrm{M} \mathrm{NaOH}$ and $10 \mathrm{mM}$ EDTA) and incubated at $98^{\circ} \mathrm{C}$ for $5 \mathrm{~min}$. The samples were immediately cooled on ice and, prior to loading on the gel, $3 \mu \mathrm{L}$ of dye solution ( $0.1 \%$ bromophenol blue, $0.1 \%$ xylene cyanol in formamide) was added. The mixture was immediately loaded onto $13.5 \%$ or $11 \%$ native polyacrylamide gel (and with addition of $3 \%$ glycerol for $13.5 \%$ gel). Electrophoresis was carried out in $0.75 \mathrm{x}$ TBE ( $45 \mathrm{mM}$ Tris, $45 \mathrm{mM}$ boric acid, $1 \mathrm{mM}$ EDTA, and pH 8.0) in DNA Pointer System (BioVectis, Poland) at three or five different temperatures. Before transferring samples onto the gel, a $100 \mathrm{Vxh} 9^{\circ} \mathrm{C}$ preelectrophoresis was performed. The MSSCP electrophoresis conditions are shown in Table 2. After electrophoresis, gels were stained using the Silver Stain Kit from BioVectis.

\section{Results}

3.1. Reverse Transcription PCR and Validation of Templates. During the experiments, different types of templates for polymerase amplification reactions were tested (Table 1). For validation of these templates, one-step RT-PCR and PCR were performed. Full genome (nR) or fusion protein fragment $(\mathrm{aR}, \mathrm{nD}$, and $\mathrm{aD})$ templates were subjected to amplification with one set of universal degenerate primers (NDF-F and NDF-R). For RT-PCR only RNA (both full genomic and $\mathrm{F}$ protein fragment transcribed from a plasmid) and for PCR only DNA (a plasmid with F protein fragment) were used. No differences were observed in the resulting products.

Until now no data have been presented whether the preamplification procedures (like using only small fragment of transcribed RNA instead of full genomic RNA for RTPCR) affect secondary ssDNA structures and their quantity, which subsequently may alter MSSCP band pattern. To check this, MSSCP analysis for RT-PCR products derived from different templates was conducted. The result is shown in Figure 2 which indicates clearly that there is no differences in ssDNA patterns irrespective of its preparation. This validates
TABLE 2: Conditions of MSSCP electrophoresis.

\begin{tabular}{lcc}
\hline Step & Vxh & Temp. $\left({ }^{\circ} \mathrm{C}\right)$ \\
\hline 1 & 600 & 9 \\
2 & 550 & 13 \\
3 & 500 & 17 \\
4 & 450 & 20 \\
5 & 400 & 23 \\
\hline
\end{tabular}

$489 \mathrm{bp}$

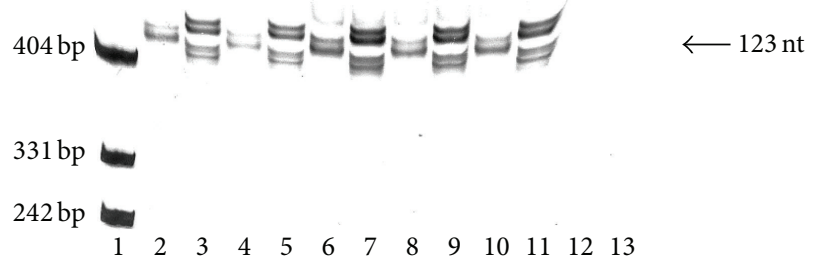

FIGURE 2: Multitemperature single-stranded conformational polymorphism (MSSCP) electrophoresis of $123 \mathrm{nt}$ fusion protein fragments of two vaccine Newcastle disease virus strains obtained from RT-PCR (lanes 2-5 and 8-11) and PCR (lanes 6 and 7). Types of templates (nR, aR, and $\mathrm{nD}$ ) were described in Section 2. Lanes: 1. Double-stranded pUC19 DNA/MspI Marker, 23 (Thermo Scientific, USA), 2. Oral swab nR La Sota, 3. Oral swab nR Roakin, 4. Cloacal swab nR La Sota, 5. Cloacal swab nR Roakin, 6. Plasmid nD La Sota, 7. Plasmid nD Roakin, 8. Allantoic fluid nR La Sota, 9. Allantoic fluid nR Roakin, 10. Transcribed RNA aR La Sota, 11. Transcribed RNA aR Roakin, 12. RT-PCR negative control, 13. PCR negative control. MSSCP was performed as described in Table 2 without the first two temperatures steps.

the use of synthetic DNA representing NDV strain or genetic variant, instead of viral genome for establishing MSSCP bands pattern.

3.2. Detection and Differentiation of "Shedding" and Quasispecies Infections. To test the ability to detect two different NDV variants in a single sample, a series of mixed template PCRs was prepared. After reaction, MSSCP analysis was performed and ssDNA band patterns were visualized as presented in Figures 3 and 4. The presence of all Australian genetic variants was clearly detected in combinations with each other and with vaccine Roakin strain.

\section{Discussion}

Low pathogenic strains of NDV in feces of infected birds can remain active for more than two months, and the virus can persist for over two years in bird population [54-56]. This has not raised much concern until the last decade of 20th century when it was found that a low pathogenic virus can transform into highly pathogenic with only four point mutations. Such spontaneous change was documented for the first time for Irish velogenic isolates in 1990 [57, 58]. At that time, Australia was considered as a continent free from highly pathogenic strains of APMV-1 [59]. However, 


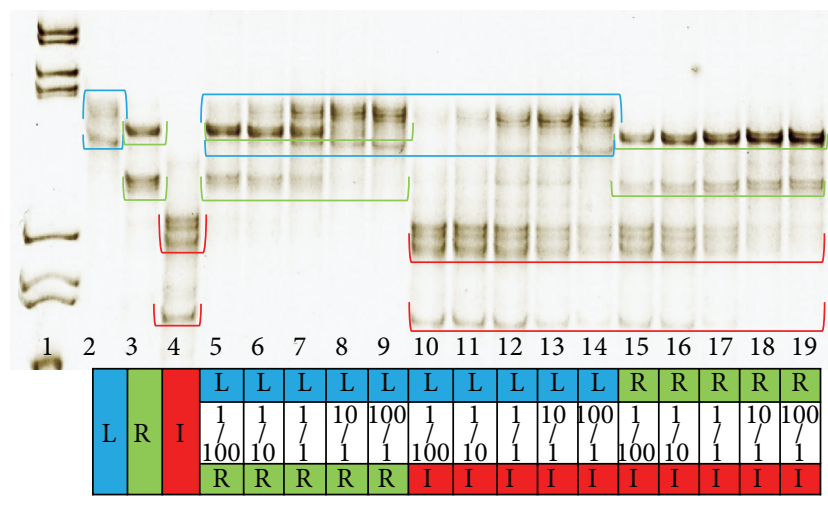

FIGURE 3: MSSCP electrophoresis of $123 \mathrm{nt}$ NDV fusion protein fragments RT-PCR and PCR products. Lanes 2-4 are RT-PCR products (genomic RNA-nR template; L-La Sota strain, RRoakin strain, and I-Italy strain) where lanes 5-19 are PCR products (plasmids with cloned fusion protein gen fragment $-\mathrm{nD}$ and $\mathrm{aD}$ templates). The PCR strains sample composition, plasmid ratio, and color code explanation can be found in the table below the figure. MSSCP was performed in $11 \%$ polyacrylamide gel without any additives as described in Table 2.

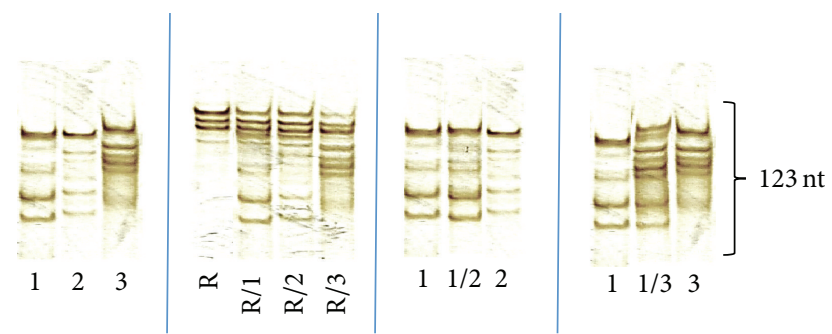

FIGURE 4: MSSCP electrophoresis of $123 \mathrm{nt}$ NDV fusion protein fragments RT-PCR products ( $\mathrm{nR}$ and aR templates). Labeling: 1. Australian lentogenic strain 98-1154, 2. Australian mesogenic strain 99-0868-2, 3. Australian velogenic strain 99-0655, R. Vaccine mesogenic Roakin strain. MSSCP was performed in $13,5 \%$ polyacrylamide gel with addition of $3 \%$ glycerol as described in Table 2.

ten years later, a similar change in virulence was observed during the outbreak that took place in 1998-2002 in the New South Wales, Australia. Two point mutations in the cleavage site of the F glycoprotein resulted in a complete change of pathotype and threatened poultry farms on the continent. It has been found that the viral population circulating in the environment consisted of a number of intermediate forms, called quasispecies $[41,60]$. The idea of constantly changing (mutating) viruses that generate different properties (e.g., virulence) in subpopulations was previously confirmed for many viruses not related to NDV [61-63]. This specific feature is most pronounced in RNA viruses because of lack of proofreading properties of RNA polymerase to efficiently repair genomes that undergo replication $[64,65]$.

The Australian case gave rise to the discussion whether it is possible to detect such events in advance. To cope with the problem we need to establish a method that will meet some basic requirements. This method must be able to detect numerous genetically altered variants in the pool of progenitor viruses as well as it must be able to distinguish between two sequences with only single nucleotide mismatch. Additional advantage of such method should be low cost and simplicity.

The combination of Reverse Transcription real-time, digital PCR with Sanger sequencing or applications of Next Generation Sequencing and oligonucleotide microarrays can give great results, but they are expensive and highly demanding for trained technician and elaborate equipment $[39,66,67]$. As an alternative, many protocols, based on techniques like restriction endonuclease analyses, peptide nucleic acid with gold nanoparticles assay, phage-capturing dot blot, in situ hybridization, RT-PCR, and probe-based real-time RT-PCR, were proposed [68-72]. Their main limitation is the need to react with a specific nucleotide sequence responsible for virulence. Single nucleotide mismatches that are responsible for acquiring virulence may not be detected and can lead to false diagnostic results $[37,38]$.

During our study, we developed a method, based on RTPCR followed by MSSCP analyses, that meets the requirements described in the second paragraph. In our opinion, fast diagnostics of a new genetic variant that appears in previously stable population could alert veterinary services and lead, after confirmation, to preventive actions for disease eradication. MSSCP can differentiate between lentogenic vaccine, mesogenic vaccine, circulating velogenic, lentogenic natural occurring, and their highly pathogenic mutated NDV variants. This can be achieved by comparison of unknown pattern of silver stained bands to previously established database of known isolates. Even without direct information about pathotype of the unknown sample, it is easy to distinguish potentially unwanted strain of NDV. The technique described above does not require highly sophisticated and expensive tools and is easy to perform by laboratory technical personnel. Additionally it is relatively inexpensive and takes about 5 minutes per sample from the end of one-step RTPCR until visualization. Main disadvantage (that has no significance for a technician performing the assay) of MSSCP is a lengthy and arduous optimization of gel run conditions like selection of optimum conditions (temperature, voltage, and time) and gel percentage of polyacrylamide and other additives.

\section{Conclusions}

Many methods have been developed that allow for detecting different pathotypes of Newcastle disease virus. One of the most popular and validated molecular techniques is realtime PCR. The disadvantage of this method is difficulty in detection of multistrain infections and minute changes in sequence that can alter virulence. In this study, we described a method based on a modification of single-stranded conformational polymorphism at specially programmed temperatures (MSSCP) that can be easily applied for NDV screening. We also showed that to prepare a library of MSSCP patterns it is not necessary to use isolated genomic material but only short synthetized nucleotides. In other words, it is possible to create a database of ssDNA band patterns for all-known 
NDV F gene sequences (e.g., available in NCBI) without need to isolate their genetic material but by synthetizing dsDNA analogs and reverse transcription to RNA. They can be used as a template for RT-PCR and produce exactly the same MSSCP ssDNA band patterns (Figure 2).

\section{Conflict of Interests}

The authors declare that there is no conflict of interests regarding the publication of this paper.

\section{Acknowledgment}

This research was cofunded by the National Centre for Research and Development within the Applied Research Programme Grant no. PBS1/B8/2/2012.

\section{References}

[1] D. J. Alexander, R. E. Gough, Y. M. Saif et al., "Newcastle disease, other avian Paramyxoviruses, and Pneumavirus infections," in Disease of Poultry, vol. 11, pp. 63-92, Iowa State Press, Ames, Iowa, USA, 2003.

[2] C. Terregino, E. W. Aldous, A. Heidari et al., "Antigenic and genetic analyses of isolate APMV/wigeon/Italy/3920-1/2005 indicate that it represents a new avian paramyxovirus (APMV12)," Archives of Virology, vol. 158, no. 11, pp. 2233-2243.

[3] M. A. Mayo, "A summary of taxonomic changes recently approved by ICTV," Archives of Virology, vol. 147, no. 8, pp. 16551656, 2002.

[4] S. C. Courtney, L. Susta, D. Gomez et al., "Highly divergent virulent isolates of Newcastle disease virus from the Dominican Republic are members of a new genotype that may have evolved unnoticed for over 2 decades," Journal of Clinical Microbiology, vol. 52, no. 2, pp. 508-517, 2012.

[5] D. G. Diel, L. H. da Silva, H. Liu, Z. Wang, P. J. Miller, and C. L. Afonso, "Genetic diversity of avian paramyxovirus type 1: proposal for a unified nomenclature and classification system of Newcastle disease virus genotypes," Infection, Genetics and Evolution, vol. 12, no. 8, pp. 1770-1779, 2012.

[6] I. Bikel and P. H. Duesberg, "Proteins of Newcastle disease virus and of the viral nucleocapsid," Journal of Virology, vol. 4, no. 4, pp. 388-393, 1969.

[7] A. Czeglédi, D. Ujvári, E. Somogyi, E. Wehmann, O. Werner, and B. Lomniczi, "Third genome size category of avian paramyxovirus serotype 1 (Newcastle disease virus) and evolutionary implications," Virus Research, vol.120, no. 1-2, pp. 36-48, 2006.

[8] R. A. Lamb and D. Kolakofsky, "Paramyxoviridae: the viruses and their replication," in Fundamental Virology, pp. 1305-1340, Lippincott-Raven Publishers, Philadelphia, Pa, USA, 2002.

[9] R. K. Plemper, A. L. Hammond, and R. Cattaneo, "Measles virus envelope glycoproteins hetero-oligomerize in the endoplasmic reticulum," Journal of Biological Chemistry, vol. 276, no. 47, pp. 44239-44246, 2001.

[10] S. Vidal and D. Kolakofsky, "Modified model for the switch from Sendai virus transcription to replication," Journal of Virology, vol. 63, no. 5, pp. 1951-1958, 1989.

[11] A. Ali and D. P. Nayak, "Assembly of Sendal virus: M protein interacts with $\mathrm{F}$ and $\mathrm{HN}$ proteins and with the cytoplasmic tail and transmembrane domain of F protein," Virology, vol. 276, no. 2, pp. 289-303, 2000.

[12] D. J. Alexander, "Newcastle disease virus and other avian Paramyxoviruses," in A Laboratory Manual for the Isolation and Identification of Avian Pathogens, pp. 156-163, American Association of Avian Pathologists, Kennett Square, Pa, USA, 4th edition, 1998.

[13] E. F. Kaleta and C. Baldauf, "Newcastle disease in free-living and pet birds," in Newcastle Disease, pp. 197-246, Kluwer Academic Publishers, Boston, Mass, USA, 1988.

[14] L. K. Csatary, R. W. Moss, J. Beuth, B. Töröcsik, J. Szeberenyi, and T. Bakacs, "Beneficial treatment of patients with advanced cancer using a Newcastle Disease Virus Vaccine (MTH-68/H)," Anticancer Research, vol. 19, no. 1, pp. 635-638, 1999.

[15] R. Kumar, A. K. Tiwari, U. Chaturvedi et al., "Velogenic newcastle disease virus as an oncolytic virotherapeutics: in vitro characterization," Applied Biochemistry and Biotechnology, vol. 167, no. 7, pp. 2005-2022, 2005.

[16] J. G. Sinkovics and J. C. Horvath, "Newcastle disease virus (NDV): brief history of its oncolytic strains," Journal of Clinical Virology, vol. 16, no. 1, pp. 1-15, 2000.

[17] H. Takakuwa, T. Ito, A. Takada, K. Okazaki, and H. Kida, "Potentially virulent Newcastle disease viruses are maintained in migratory waterfowl populations," Japanese Journal of Veterinary Research, vol. 45, no. 4, pp. 207-215, 1998.

[18] D. Ujvári, E. Wehmann, E. F. Kaleta et al., "Phylogenetic analysis reveals extensive evolution of avian paramyxovirus type 1 strains of pigeons (Columba livia) and suggests multiple species transmission," Virus Research, vol. 96, no. 1-2, pp. 63-73, 2003.

[19] R. Rott and H. D. Klenk, "Molecular basis of infectivity and pathogenicity of Newcastle disease virus," in Newcastle Disease, pp. 197-246, Kluwer Academic Publishers, Boston, Mass, USA, 1988.

[20] M. S. Collins, I. Strong, and D. J. Alexander, "Pathogenicity and phylogenetic evaluation of the variant Newcastle disease viruses termed "pigeon PMV-1 viruses" based on the nucleotide sequence of the fusion protein gene," Archives of Virology, vol. 141, no. 3-4, pp. 635-647, 1996.

[21] Y. Nagai, H. D. Klenk, and R. Rott, "Proteolytic cleavage of the viral glycoproteins and its significance for the virulence of Newcastle disease virus," Virology, vol. 72, no. 2, pp. 494-508, 1976.

[22] OIE, Manual of Diagnostic Tests and Vaccines for Terrestrial Animals, vol. 1-2, 7th edition, 2012.

[23] P. J. Miller, C. Estevez, Q. Yu, D. L. Suarez, and D. J. King, "Comparison of viral shedding following vaccination with inactivated and live newcastle disease vaccines formulated with wild-type and recombinant viruses," Avian Diseases, vol. 53, no. 1, pp. 3949, 2009.

[24] K. Nakamura, M. Ito, T. Nakamura et al., "Pathogenesis of Newcastle disease in vaccinated chickens: pathogenicity of isolated virus and vaccine effect on challenge of its virus," Journal of Veterinary Medical Science, vol. 76, no. 1, pp. 31-36, 2013.

[25] P. J. Miller, C. L. Afonso, J. El Attrache et al., "Effects of Newcastle disease virus vaccine antibodies on the shedding and transmission of challenge viruses," Developmental and Comparative Immunology, vol. 41, no. 4, pp. 505-513, 2013.

[26] J. C. F. M. Dortmans, B. P. H. Peeters, and G. Koch, "Newcastle disease virus outbreaks: vaccine mismatch or inadequate application?" Veterinary Microbiology, vol. 160, pp. 17-22, 2012. 
[27] M. G. Wise, D. L. Suarez, B. S. Seal et al., "Development of a real-time reverse-transcription PCR for detection of newcastle disease virus RNA in clinical samples," Journal of Clinical Microbiology, vol. 42, no. 1, pp. 329-338, 2004.

[28] C. M. Fuller, M. S. Collins, and D. J. Alexander, "Development of a real-time reverse-transcription PCR for the detection and simultaneous pathotyping of Newcastle disease virus isolates using a novel probe," Archives of Virology, vol. 154, no. 6, pp. 929-937, 2009.

[29] D. Nidzworski, L. Rabalski, and B. Gromadzka, "Detection and differentiation of virulent and avirulent strains of Newcastle disease virus by real-time PCR," Journal of Virological Methods, vol. 173, no. 1, pp. 144-149, 2011.

[30] S. W. Tan, A. Ideris, A. R. Omar, K. Yusoff, and M. HairBejo, "Detection and differentiation of velogenic and lentogenic Newcastle disease viruses using SYBR Green I real-time PCR with nucleocapsid gene-specific primers," Journal of Virological Methods, vol. 160, no. 1-2, pp. 149-156, 2009.

[31] H. M. Pham, S. Konnai, T. Usui et al., "Rapid detection and differentiation of Newcastle disease virus by real-time PCR with melting-curve analysis," Archives of Virology, vol. 150, no. 12, pp. 2429-2438, 2005.

[32] A. Yacoub, M. Leijon, M. J. McMenamy et al., "Development of a novel real-time PCR-based strategy for simple and rapid molecular pathotyping of Newcastle disease virus," Archives of Virology, vol. 157, no. 5, pp. 833-844, 2012.

[33] T. Farkas, É. Székely, S. Belák, and I. Kiss, "Real-time PCR-based pathotyping of newcastle disease virus by use of TaqMan minor groove binder probes," Journal of Clinical Microbiology, vol. 47, no. 7, pp. 2114-2123, 2009.

[34] L. M. Kim, D. L. Suarez, and C. L. Afonso, "Detection of a broad range of class $\mathrm{i}$ and II Newcastle disease viruses using a multiplex real-time reverse transcription polymerase chain reaction assay," Journal of Veterinary Diagnostic Investigation, vol. 20 , no. 4 , pp. 414-425, 2008.

[35] E. W. Aldous, M. S. Collins, A. McGoldrick, and D. J. Alexander, "Rapid pathotyping of Newcastle disease virus (NDV) using fluorogenic probes in a PCR assay," Veterinary Microbiology, vol. 80, no. 3, pp. 201-212, 2001.

[36] L. Zhang, Z. Pan, S. Geng et al., "Sensitive, semi-nested RT-PCR amplification of fusion gene sequences for the rapid detection and differentiation of Newcastle disease virus," Research in Veterinary Science, vol. 89, no. 2, pp. 282-289, 2010.

[37] G. Cattoli, C. De Battisti, S. Marciano et al., "False-negative results of a validated real-time PCR protocol for diagnosis of newcastle disease due to genetic variability of the matrix gene," Journal of Clinical Microbiology, vol. 47, no. 11, pp. 3791-3792, 2009.

[38] L. M. Kim, C. L. Afonso, and D. L. Suarez, "Effect of probesite mismatches on detection of virulent Newcastle disease viruses using a fusion-gene real-time reverse transcription polymerase chain reaction test," Journal of Veterinary Diagnostic Investigation, vol. 18, no. 6, pp. 519-528, 2006.

[39] N. Chen, B. A. Pinsky, B. P. Lee, M. Lin, and I. Schrijver, "Ultrasensitive detection of drug-resistant pandemic 2009 (H1N1) influenza A virus by rare-variant-sensitive high-resolution melting-curve analysis," Journal of Clinical Microbiology, vol. 49, no. 7, pp. 2602-2609, 2011.

[40] A. R. Gould, J. A. Kattenbelt, P. Selleck, E. Hansson, A. DellaPorta, and H. A. Westbury, "Virulent Newcastle disease in Australia: molecular epidemiological analysis of viruses isolated prior to and during the outbreaks of 1998-2000," Virus Research, vol. 77, no. 1, pp. 51-60, 2001.

[41] J. A. Kattenbelt, M. P. Stevens, P. W. Selleck, and A. R. Gould, "Analysis of Newcastle disease virus quasispecies and factors affecting the emergence of virulent virus," Archives of Virology, vol. 155, no. 10, pp. 1607-1615, 2010.

[42] O. S. de Leeuw, L. Hartog, G. Koch, and B. P. H. Peeters, "Effect of fusion protein cleavage site mutations on virulence of Newcastle disease virus: non-virulent cleavage site mutants revert to virulence after one passage in chicken brain," Journal of General Virology, vol. 84, no. 2, pp. 475-484, 2003.

[43] Y. Shengqing, N. Kishida, H. Ito et al., "Generation of velogenic Newcastle disease viruses from a nonpathogenic waterfowl isolate by passaging in chickens," Virology, vol. 301, no. 2, pp. 206-211, 2002.

[44] M. Orita, H. Iwahana, H. Kanazawa, K. Hayashi, and T. Sekiya, "Detection of polymorphisms of human DNA by gel electrophoresis as single-strand conformation polymorphisms," Proceedings of the National Academy of Sciences of the United States of America, vol. 86, no. 8, pp. 2766-2770, 1989.

[45] W. E. Highsmith, A. J. Nataraj, Q. Jin et al., "Use of DNA toolbox for the characterization of mutation scanning methods. II: evaluation of single-strand conformation polymorphism analysis," Electrophoresis, vol. 20, pp. 1195-1203, 1999.

[46] A. J. Nataraj, I. Olivos-Glander, N. Kusukawa, and W. E. Highsmith Jr., "Single-strand conformation polymorphism and heteroduplex analysis for gel-based mutation detection," Electrophoresis, vol. 20, pp. 1177-1185, 1999.

[47] C. D. O'Connell, D. H. Atha, M. C. Oldenburg et al., "Detection of p53 gene mutation: analysis by single-strand conformation polymorphism and cleavage fragment length polymorphism," Electrophoresis, vol. 20, pp. 1211-1223, 1999.

[48] R. Kaczanowski, L. Trzeciak, and K. Kucharczyk, "Multitemperature single-strand conformation polymorphism," Electrophoresis, vol. 22, pp. 3539-3545, 2001.

[49] J. D. Quinto and C. K. Wang, "A high throughput singlestranded conformation polymorphism assay for detection, subtyping and genotyping of influenza viruses," International Congress Series, vol. 1263, pp. 653-657, 2004.

[50] V. Y. Lugovtsev, G. M. Vodeiko, C. M. Strupczewski, and R. A. Levandowski, "Simple and rapid strategy for genetic characterization of influenza B virus reassortants," Journal of Virological Methods, vol. 124, no. 1-2, pp. 203-210, 2005.

[51] B. Szewczyk, P. Barski, W. Sihler et al., "Detection and identification of baculovirus pesticides by multitemperature singlestrand conformational polymorphism," Journal of Environmental Science and Health, Part B: Pesticides, Food Contaminants, and Agricultural Wastes, vol. 43, no. 7, pp. 539-545, 2008.

[52] G. Stamenkovic, J. Guduric, Z. Velickovic et al., "Analysis of $5^{\prime}$ non-coding region in hepatitis $\mathrm{C}$ virus by single-strand conformation polymorphism and low-stringency single specific primer PCR," Clinical Chemistry and Laboratory Medicine, vol. 39, no. 10, pp. 948-952, 2001.

[53] A. M. Roque-Afonso, D. Ducoulombier, G. Di Liberto et al., "Compartmentalization of hepatitis $\mathrm{C}$ virus genotypes between plasma and peripheral blood mononuclear cells," Journal of Virology, vol. 79, no. 10, pp. 6349-6357, 2005.

[54] D. R. Kapczynski and D. J. King, "Protection of chickens against overt clinical disease and determination of viral shedding following vaccination with commercially available Newcastle disease virus vaccines upon challenge with highly virulent virus 
from the California 2002 exotic Newcastle disease outbreak," Vaccine, vol. 23, no. 26, pp. 3424-3433, 2005.

[55] J. L. Samuel and P. B. Spradbrow, "Persistence of the V4 strain of Newcastle disease virus in an open-range flock of chickens," Veterinary Record, vol. 124, no. 8, pp. 193-196, 1989.

[56] M. Frölich, S. Cortez de Jäckel, and T. Selhorst, "The tenacity of Newcastle disease virus (LaSota) in the excrement of laying hens in different housing systems," Deutsche Tierarztliche Wochenschrift, vol. 99, no. 12, pp. 494-499, 1992.

[57] M. S. Collins, J. B. Bashiruddin, and D. J. Alexander, "Deduced amino acid sequences at the fusion protein cleavage site of Newcastle disease viruses showing variation in antigenicity and pathogenicity," Archives of Virology, vol. 128, no. 3-4, pp. 363370, 1993.

[58] M. S. Collins, S. Franklin, I. Strong, G. Meulemans, and D. J. Alexander, "Antigenic and phylogenetic studies on a variant Newcastle disease virus using anti-fusion protein monoclonal antibodies and partial sequencing of the fusion protein gene," Avian Pathology, vol. 27, no. 1, pp. 90-96, 1998.

[59] P. B. Spradbrow, M. MacKenzie, and S. E. Grimes, "Recent isolates of Newcastle disease virus in Australia," Veterinary Microbiology, vol. 46, no. 1-3, pp. 21-28, 1995.

[60] J. A. Kattenbelt, M. P. Stevens, and A. R. Gould, "Sequence variation in the Newcastle disease virus genome," Virus Research, vol. 116, no. 1-2, pp. 168-184, 2006.

[61] E. L. Delwart and C. J. Gordon, "Tracking changes in HIV1 envelope quasispecies using DNA heteroduplex analysis," Methods, vol. 12, no. 4, pp. 348-354, 1997.

[62] G. Sánchez, A. Bosch, G. Gómez-Mariano, E. Domingo, and R. M. Pintó, "Evidence for quasispecies distributions in the human hepatitis A virus genome," Virology, vol. 315, no. 1, pp. 34-42, 2003.

[63] M. Figlerowicz, P. Jackowiak, P. Formanowicz et al., "Hepatitis C virus quasispecies in chronically infected children subjected to interferon-ribavirin therapy," Archives of Virology, vol. 155, no. 12, pp. 1977-1987, 2010.

[64] E. Domingo, C. Escarmis, N. Sevilla et al., "Basic concepts in RNA virus evolution," The Journal of the Federation of American Societies for Experimental Biology, vol. 10, pp. 859-864, 1996.

[65] A. S. Lauring, J. Frydman, and R. Andino, "The role of mutational robustness in RNA virus evolution," Nature Reviews: Microbiology, vol. 11, no. 5, pp. 327-336, 2013.

[66] C. de Battisti, A. Salomoni, S. Ormelli, I. Monne, I. Capua, and G. Cattoli, "Rapid pathotyping of Newcastle Disease Virus by pyrosequencing," Journal of Virological Methods, vol. 188, no. 12, pp. 13-20, 2013.

[67] O. Lung, A. Beeston, S. Ohen-Adjei et al., "Electronic microarray assays for avian influenza and Newcastle disease virus," Journal of Virological Methods, vol. 185, no. 2, pp. 244-253, 2012.

[68] M. Mase and K. Kenehira, "Simple differentiation of avirulent and virulent strains of avian paramyxovirus serotype-1 (Newcastle disease virus) by PCR and restriction endonuclease analysis in Japan," Journal of Veterinary Medical Science, vol. 74, no. 12, pp. 1661-1664, 2012.

[69] V. G. Joshi, K. Chindera, A. K. Singh et al., "Rapid labelfree visual assay for the detection and quantification of viral RNA using peptide nucleic acid (PNA) and gold nanoparticles (AuNPs)," Analytica Chimica Acta, vol. 759, pp. 1-7, 2013.

[70] I. Oldoni, C. C. Brown, D. J. King, S. Samal, and B. S. Seal, “The use of in situ hybridization and immunohistochemistry to study the pathogenesis of various Newcastle disease virus strains and recombinants in embryonated chicken eggs," Microbial Pathogenesis, vol. 39, no. 3, pp. 69-75, 2005.

[71] A. K. Tiwari, R. S. Kataria, T. Nanthakumar, B. B. Dash, and G. Desai, "Differential detection of Newcastle disease virus strains by degenerate primers based RT-PCR," Comparative Immunology, Microbiology and Infectious Diseases, vol. 27, no. 3, pp. 163-169, 2004.

[72] T. C. Lee, K. Yusoff, S. Nathan, and W. S. Tan, "Detection of virulent Newcastle disease virus using a phage-capturing dot blot assay," Journal of Virological Methods, vol. 136, no. 1-2, pp. 224-229, 2006.

[73] A. Daniel, Charakterystyka krajowych szczepów wirusa rzekomego pomoru drobiu z uwzględnieniem zastosowania przeciwciat monoklonalnych [Ph.D. thesis], PIWet-PIB, Pulawy, Poland, 2004. 

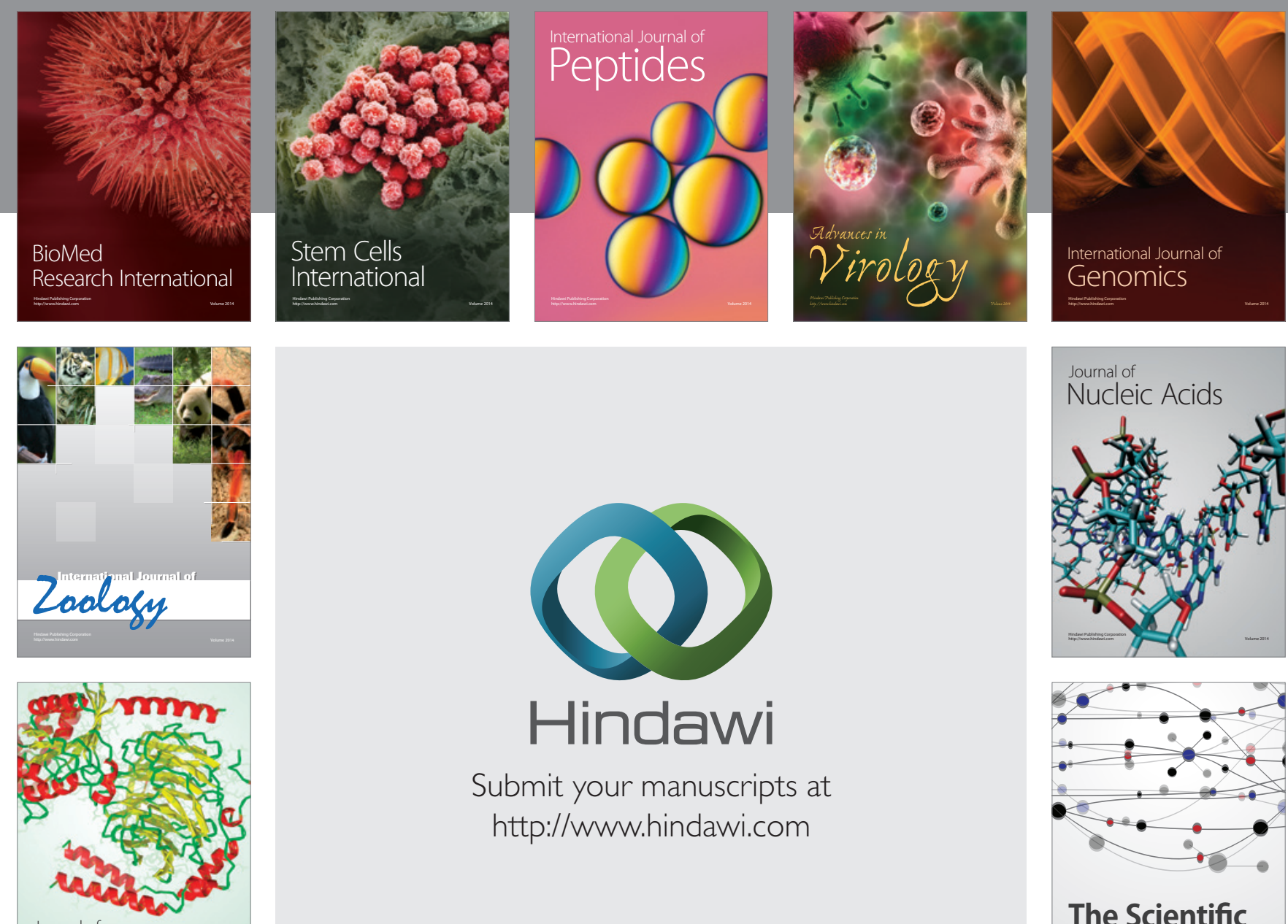

Submit your manuscripts at

http://www.hindawi.com

Journal of
Signal Transduction
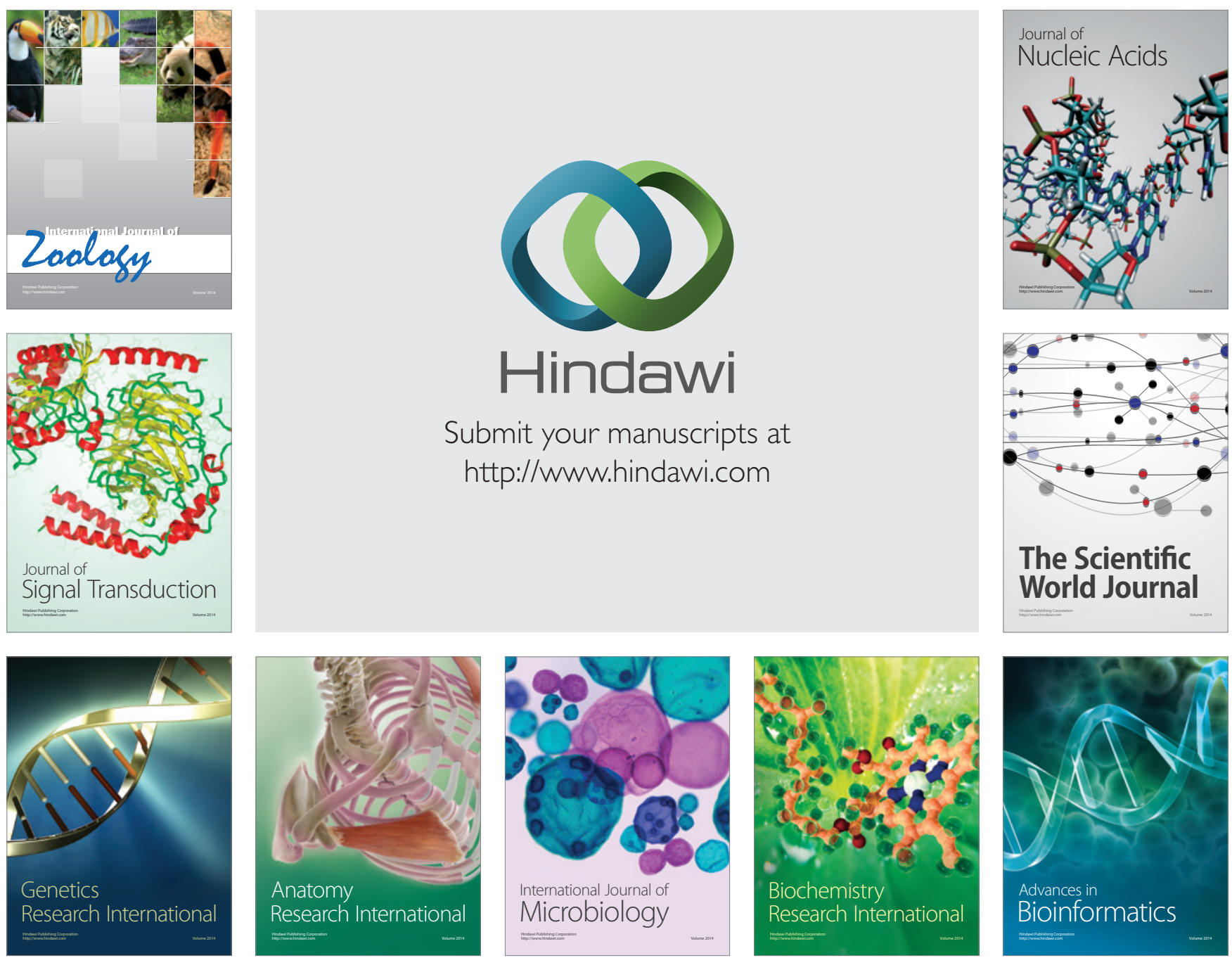

The Scientific World Journal
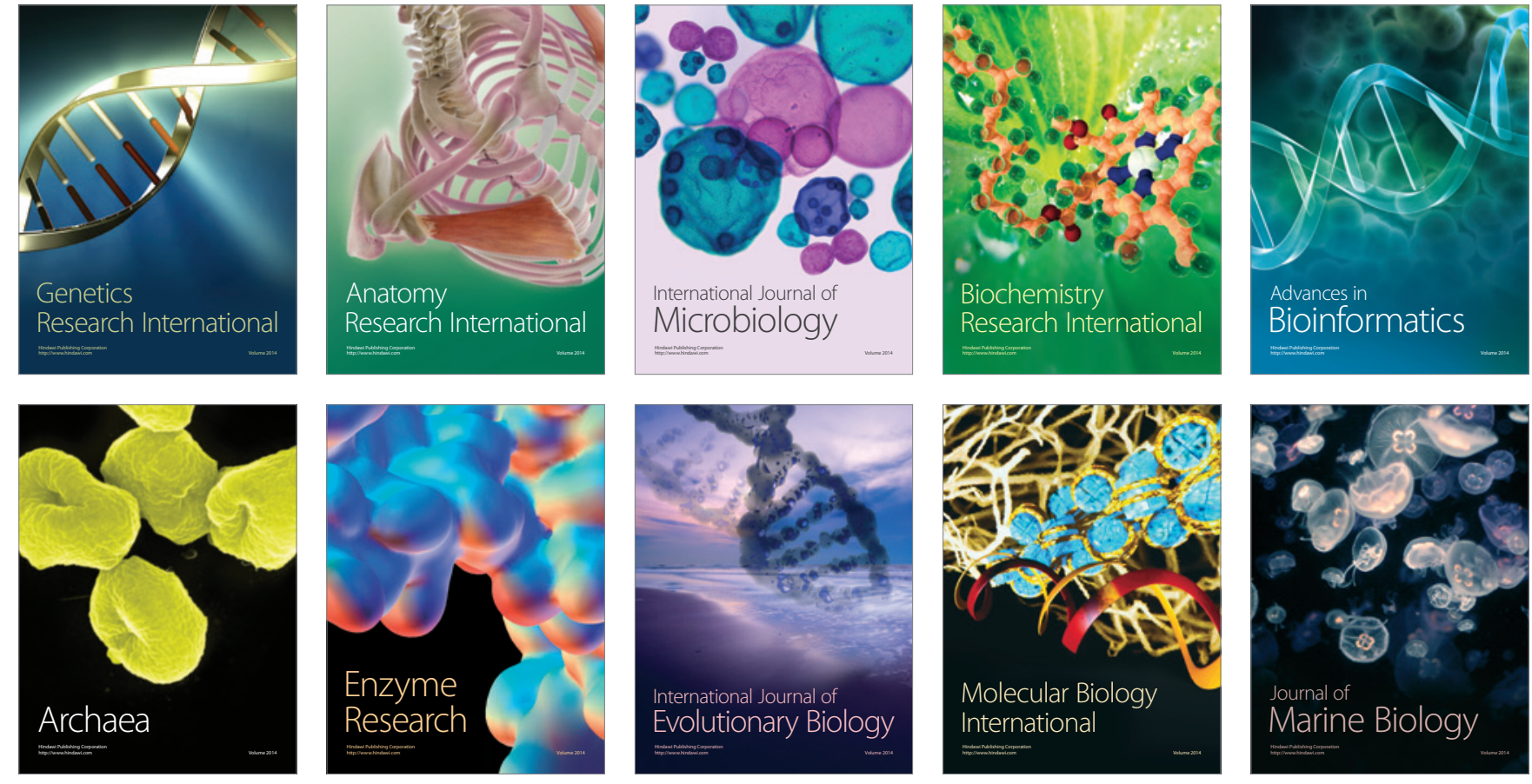